\title{
A Synoptic Study on the Preparation of a Liquid Waste Management Plan for Kerala State, India
}

\author{
P S Harikumar $^{1} \&$ Bindhya Mol K ${ }^{1}$ \\ ${ }^{1}$ Water Quality Division, Centre for Water Resources Development and Management, Kerala, India \\ Correspondence: P S Harikumar, Water Quality Division, Centre for Water Resources Development and \\ Management, Kerala, India. Tel: 91-495-235-1871. E-mail: drpshari@yahoo.co.in
}

Received: April 12, 2012 Accepted: May 17, 2012 Online Published: June 1, 2012

doi:10.5539/enrr.v2n2p74 URL: http://dx.doi.org/10.5539/enrr.v2n2p74

\begin{abstract}
Kerala is one of the smallest States in India ( $38863 \mathrm{Sq} \mathrm{km}$ ) covering merely $1.18 \%$ of the total area of the country and is situated between $8^{\circ} 18^{\prime}$ and $12^{\circ} 48^{\prime} \mathrm{N}$ latitude and $74^{\circ} 52^{\prime}$ and $77^{\circ} 22^{\prime} \mathrm{E}$ longitude. Kerala has $3.44 \%$ of India's population; at 819 persons per square $\mathrm{km}$. Because of the inadequate sewage treatment facilities, the natural water bodies of the State are polluted with wastewater discharge. A sectoral study was carried out to understand the existing problems of liquid waste disposal and the management of wastewater. Three Panchayats, two municipalities and a Corporation were selected for the study. A total number of 825 families were surveyed using a questionnaire in the form of social survey to understand the existing liquid waste management problems. From the study it was found that percapita consumption of water in the study area varied from 183 lpcd to 148 lpcd. A total number of 59 wastewater samples were collected and analysed for various physico chemical and bacteriological analysis. Workshops were conducted among elected representatives and other stakeholders for the effective preparation of a liquid waste management plan. A pilot study was conducted for wastewater management using constructed wetland method. The study concluded that constructed wetland can be recommended as one of the cost effective and efficient methods for wastewater treatment. The paper also discusses various steps involved for preparing an effective liquid waste management plan.
\end{abstract}

Keywords: water consumption, greywater, wastewater management, constructed wetland

\section{Introduction}

Water scarcity is a critical problem in some countries, but water quality seems to be the major problem in almost all developing countries (Innocent \& Hubb, 2005). India has been successful in meeting water requirement for different use. However, preserving the quality and sustainability of freshwater resource are major challenges. The water quality report of Central Pollution Control Board (CPCB), India during 1995 to 2006 indicate that the organic and bacterial contamination continue to be critical in water bodies. This is mainly due to the discharge of domestic wastewater mostly in an untreated form, from the urban centre of the country (Pawan, Dyanand, Sathish, \& Tapan, 2009).

Domestic wastewater, or "sewage", can be divided into two categories; black water and greywater. The term "greywater" refers to untreated household wastewater, which has not been contaminated by toilet waste. It includes the water from bathtubs, showers, hand basins, laundry tubs and washing machines. Greywater is called so because it turned grey when stored for a short periods of time (World Health Organisation [WHO], 2006). Sanitary experts define greywater as water that of less quality than potable water but of higher quality than black water. Black water is one of the most significant source of human pathogens., Separation of greywater form black water will dramatically reduce the danger posed by such pathogens (Ahmad, Abbas, Lama, \& Niveen, 2006). Household greywater is the major component of municipal sewage. If the quantity of sewage is more, the receiving water will become polluted or the land will become sewage sick. Under such circumstances it becomes essential to treat the sewage, so that the land or receiving water body can accept the treated water without any objections (Srinivas, Raveendra, \& Pradeep, 2008).

Kerala is one of the densest States of India. Kerala has moderately high rainfall $(3000 \mathrm{~mm})$, fairly large number of rivers, chains of back water bodies and number of ponds But most of these natural water bodies are polluted with bacterial contamination, which is mainly due to the direct discharge of wastewater (both greywater and black water) from the municipal sector(Environmental Monitoring Programme on Water Quality, 2009). Kerala 
has very low coverage of sewage treatment facility. Except Thiruvananthapuram ( $30 \%$ coverage) and Kochi (5\% coverage), no other cities in Kerala have sewage treatment facility. The untreated sewage pollutes the rivers, lakes and groundwater, which are the primary drinking water source of the State. A detailed study was undertaken to understand the issues of improper wastewater disposal and explored the possibilities of better management of liquid waste at domestic and community level.

The study tried to examine the existing problems and effective management of wastewater disposal in Kerala through a sectoral study in the selected local bodies of the State. As part of the study, the average percapita water consumption, greywater generation, existing sewage system, people's perception towards wastewater disposal etc. were assessed through a questionnaire survey. Different technical options including wastewater recycling using constructed wetland are suggested as part of the project.

\section{Materials and Methods}

\subsection{Study Area}

Kerala State is divided into 14 districts, on the basis of geographical, historical and cultural similarities. The State has 21 revenue divisions, 14 District Panchayats, 63 Taluks, 152 CD blocks, 1453 Revenue Villages, 999 Grama Panchayat, five Corporations and 53 Municipalities. For the study, six local bodies of Kerala State were selected, they were: Athiyannur Panchayat, Azhikode Panchayat, Omassery Panchayat, Ponnani Municipality, Kottaym Municipality and Calicut Corporation, see Table.1. Kerala State is classified into low land, middle land and high land because of the geomorphologic characteristics. Low land region having an elevation of $3 \mathrm{~m}$ to $12 \mathrm{~m}$ above Mean Sea Level (MSL), middle land region having an elevation range between $7.5 \mathrm{~m}$ to $75 \mathrm{~m}$ and the highland region comprises mainly of mountains $75 \mathrm{~m}$ above sea level (Hydrology Project- Kerala, 2011) The study area covered high land, mid land and low land region of the State and also represents the urban and rural area. The three Panchayats represent the rural area and municipalities and the corporation represent urban area of the State. The study areas are shown in Figure 1.

Table 1. Details of study area

\begin{tabular}{lllll}
\hline Sl. No. & Name of Panchayat/Municipality/Corporation & $\begin{array}{l}\text { Area, } \\
\text { sq. km }\end{array}$ & Population & $\begin{array}{l}\text { Density of } \\
\text { population }\end{array}$ \\
\hline 1 & $\begin{array}{l}\text { Athiyannur Panchayat, Thiruvananthapuram } \\
\text { District (Midland) }\end{array}$ & 12.44 & 23525 & 1890 \\
& $\begin{array}{l}\text { Omassery Panchayat, Calicut District (Highland) } \\
2\end{array}$ & 25.46 & 25420 & 998 \\
3 & $\begin{array}{l}\text { Azhikode Panchayat, Kannur District (Lowland) } \\
4\end{array}$ & 16.04 & 39838 & 2938 \\
& $\begin{array}{l}\text { Kottayam Municipality } \\
\text { (Midland) }\end{array}$ & 15.55 & 63155 & 4061 \\
& $\begin{array}{l}\text { Ponnani Municipality } \\
\text { (Lowland) }\end{array}$ & 9.32 & 51770 & 5555 \\
6 & Calicut Corporation & 82.68 & 436527 & 5078 \\
\hline
\end{tabular}

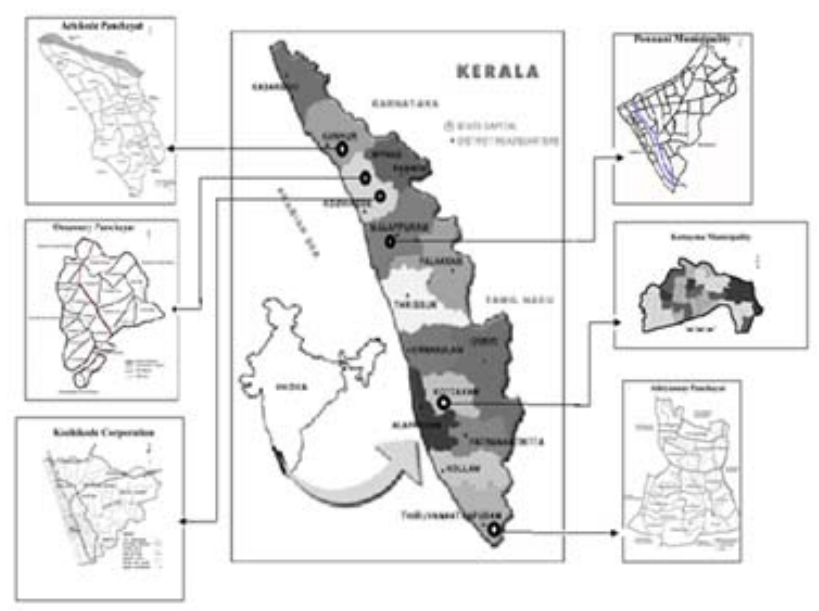

Figure 1. Various study area of Kerala State 


\subsection{Social Survey}

The amount of wastewater generated by any household will vary greatly according to the dynamics of the household, and is influenced by factors such as the number of occupants, the age distribution of the occupants, their lifestyle characteristics, water-usage patterns, the cost of water and the climate (WHO, 2006). A questionnaire in the form of social survey was designed and administrated to assess potential greywater generation in various local bodies of Kerala. A total number of 825 persons were interviewed as part of the study (Table 2). A questionnaire was used to collect the data on name of the respondent, number of occupants, type of dwelling, source of water, capacity of water tank, days of use of one water tank, number of bathrooms or toilets in the house, type of closet, type of waste tank, mode of washing clothes, number and type of domestic animals, frequency of washing the animals and their shelter, type and number of vehicle and the frequency of washing, the existence of the kitchen garden or lawn, and mode of disposal of waste water etc. The suggestions from the persons for better management of wastewater disposal was collected and documented.

Table 2. Distribution of respondents in each study area

\begin{tabular}{clc}
\hline Sl. & \multicolumn{1}{c}{ Study Area } & Number of persons interviewed \\
No. & Athiyannur Gram Panchayat & 83 \\
1. & Omassery Gram Panchayat & 69 \\
2. & Azhikode Gram Panchayat & 73 \\
3. & Kottayam Municipality & 378 \\
4. & Ponnani Municipality & 67 \\
5. & Calicut City Corporation & 155 \\
6. & Total & 825 \\
\hline
\end{tabular}

The respondents were selected by simple random method. For analysis, the respondents were classified into high income, middle income and low income groups. The criteria used for classification of respondents are given in Table 3. The total water use in an area was estimated by multiplying average percapita consumption with the total population of that area. From the total water use, $80 \%$ is discharged as wastewater. Much of the daily-generated wastewater is recognized as greywater. The total volume of greywater from the average household represents about $60 \%$ of the total generated wastewater (WHO, 2006). The total greywater discharge in an area was also estimated by multiplying average percapita discharge with the total population of that area.

Table 3. Criteria for the classification of various groups of respondents

\begin{tabular}{|c|c|}
\hline High income group & $\begin{array}{l}\text {-Land owned } \\
\text {-Concrete house } \\
\text {-Four wheeler vehicle owned } \\
\text {-Business } \\
\text {-Has kitchen garden or lawn } \\
\text { - More than three bathrooms or toilets }\end{array}$ \\
\hline Middle income group & $\begin{array}{l}\text {-Land owned } \\
\text {-Concrete house } \\
\text {-Two wheeler vehicle owned } \\
\text {-Employed } \\
\text {-Own domestic animals } \\
\text {-Own washing machine } \\
\text {-Land owned } \\
\text {-Tiled house } \\
\text {-No vehicle } \\
\text {-Not employed } \\
\text {-Own domestic animals } \\
\text {-Washing clothes by hand }\end{array}$ \\
\hline
\end{tabular}




\subsection{Wastewater Characteristics}

Total number of 59 samples were collected from a pre fixed network of sampling stations in the study area during monsoon (July, 2009) and post monsoon seasons (October, 2009) for getting information on the characteristics of greywater. The greywater samples were analyzed for important physical, chemical, and biological water quality parameters. These included; $\mathrm{pH}$, electrical conductivity, alkalinity, dissolved and suspended solids, chloride, sulphate, fluoride, phosphate, calcium, magnesium, iron, ammonical nitrogen, oil \& grease, chemical oxygen demand, biochemical oxygen demand, total coliform, faecal coliform and E.Coli. Analysis were carried as per the Standard Methods for the Examination of Water and Wastewater (APHA, 2006). Distilled water was used for dilution where needed. Blanks and control were used.

\subsection{Workshop/Discussion}

Knowledge of local people should be recognized and participatory approaches need to be applied when investigating integrated water resource management for small communities (Sahar et al., 2008). The perceptions of people towards wastewater management were also collected through the workshop/ discussions conducted in the study areas. Many stakeholder workshops were conducted in the study area to sensitise the local people and authorities on proper liquid waste management. Available options for liquid waste management were discussed in the workshop.

\subsection{Wastewater Treatment}

An experimental study was conducted for wastewater recycling using constructed wetland. The wastewater was allowed to pass through six different tanks viz, sedimentation tank, skimming tank, filtration tank, storage tank for primary treatment. The wastewater after primary treatment was further polished in constructed wetland. The locally available plants such as; Scripus Lacustris, Phragmites, Acorus calamus and Lagenandra meeboldi were used in the constructed wetland. The samples after primary and secondary treatment were collected and further treated using constructed wetland

\section{Results}

\subsection{Water Use and Greywater Discharge}

The average percapita water consumption, total water use and potential greywater availability in the study area were estimated. The results indicate that the percapita consumption of water in the study area varied from 148 litres to 183 litres with an average of 160 litres. The water use in the urban and rural areas did not show much variation.

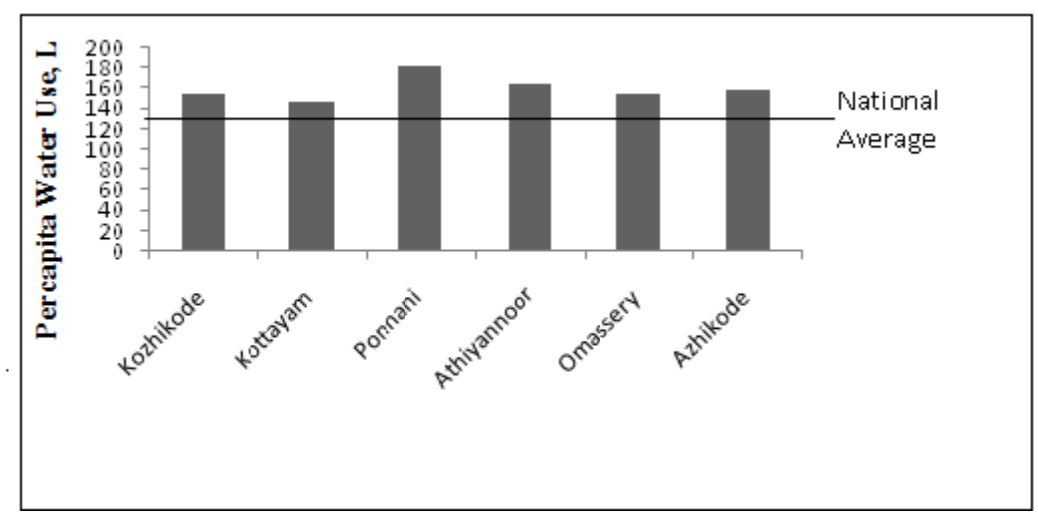

Figure 2. Comparision of percapita water consumption in various study area

As per a report published by United Nations Development Program (UNDP, 2006), average percapita water use in India is $135 \mathrm{~L}$ per day. As shown in Figure 2, the average water consumption in all study area is higher when compared with the national average. The water consumption in Ponnani Municipality reported higher variation and Kottayam Municipality reported lower variation when compared with national average.

For further analysis the data obtained from the 825 respondents were classified based on their standard of living viz., high income group, middle income group and low income group. Descriptive statistical analysis was performed to examine the average, minimum, maximum as well as standard deviation of the percapita water 
usage. The results are presented in Table 4. The 6 selected local bodies of the study area represent the physiographical and geographical region of the Kerala State and also represent the urban and rural area of the State. So the data obtained from the study will represent the various liquid waste management aspects of the Sate. Water usage pattern of Kerala State were derived from Table. 4. The average percapita water usage was found to be 160lpcd. Percapita water use of high income group varies from $183 \mathrm{~L}$ to $242 \mathrm{~L}$, middle income group 140L to $188 \mathrm{~L}$ and low income group $72 \mathrm{~L}$ to $122 \mathrm{~L}$ with the standard deviations of 23,20 , and 13 respectively. As shown in Figure 3, high income group and middle income group used more water than the national average and the amount of water used by low income group was below the national average. From this data it can be interpreted that standard of living influence the water consumption of the people.

Table 4. Percapita water usage of various study area

\begin{tabular}{llllll}
\hline & \multicolumn{3}{l}{ Percapita Water Usage, lpcd } \\
& Average & $\begin{array}{l}\text { High } \\
\text { Group }\end{array}$ & $\begin{array}{l}\text { Income } \\
\text { Middle } \\
\text { Group }\end{array}$ & $\begin{array}{l}\text { Income } \\
\text { Low Income } \\
\text { Group }\end{array}$ \\
\hline Calicut Corporation & 154 & 211 & 166 & 85 \\
Kottayam Municipality & 148 & 183 & 136 & 122 \\
Ponnani Municipality & 183 & 242 & 183 & 120 \\
Omassery Panchayat & 154 & 239 & 146 & 110 \\
Azhikode Panchayat & 158 & 233 & 135 & 106 \\
Athiyannoor Panchayat & 165 & 239 & 135 & 106 \\
Minimum & 148 & 183 & 135 & 85 \\
Maximum & 183 & 242 & 183 & 122 \\
Average & 160 & 225 & 150 & 108 \\
Standard Deviation & 12 & 23 & 20 & 13 \\
\hline
\end{tabular}

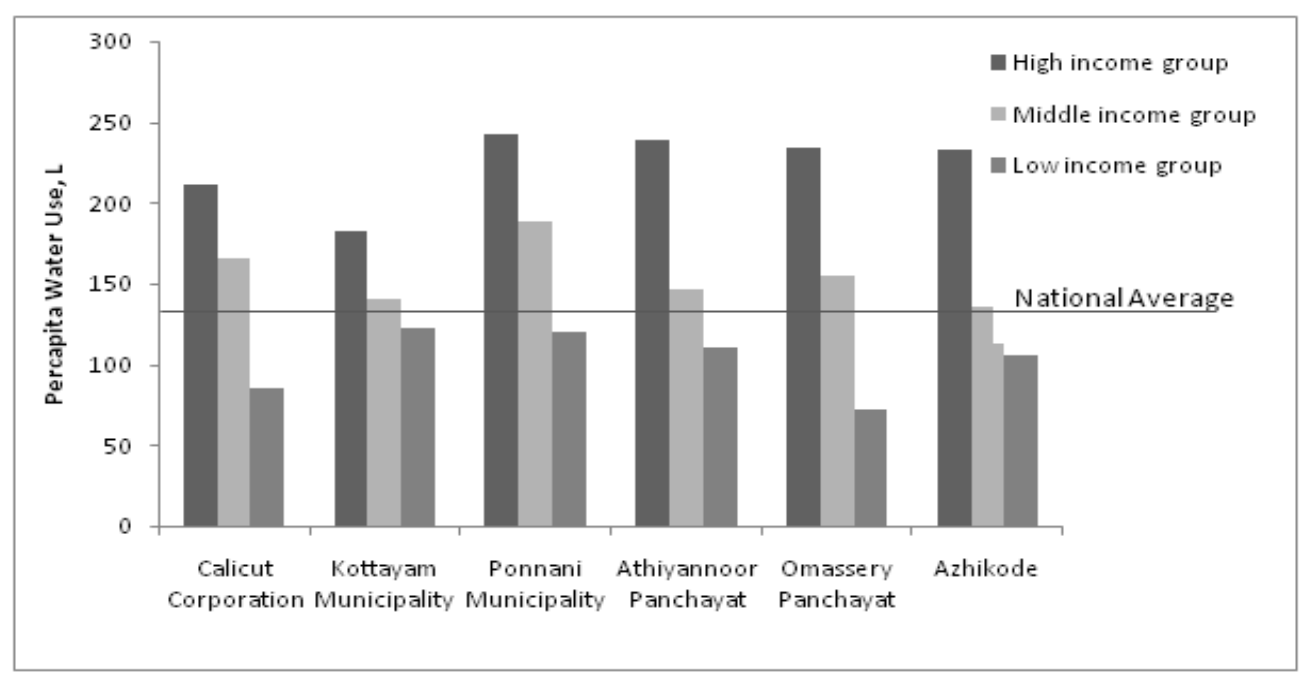

Figure 3. Comparision of percapita water consumption according to standard of living

Household wastewater and greywater generation were also estimated. The total waste water use and greywater of the area was calculated my multiplying percapita wastewater and greywater with the population (Table. 5). From 
the result, it was noted that, urban areas produced large volume of wastewater. Calicut Corporation itself produces 32.27MLD of greywater. The greywater can be recycled and use for many domestic purposes including gardening washing, toilet flushing etc. In the rural areas of the study, Azhikode Panchayat discharges comparatively higher amount of wastewater compared to other two Panchayats.

Table 5. Comparison of water use and wastewater discharge in the study area

\begin{tabular}{ccccccc}
\hline Classifications & $\begin{array}{c}\text { Calicut } \\
\text { Corporation }\end{array}$ & $\begin{array}{c}\text { Urban } \\
\text { Kottayam } \\
\text { Municipality }\end{array}$ & $\begin{array}{c}\text { Ponnani } \\
\text { Municipality }\end{array}$ & $\begin{array}{c}\text { Athiyannoor } \\
\text { Panchayat }\end{array}$ & $\begin{array}{c}\text { Rural } \\
\text { Omassery } \\
\text { Panchayat }\end{array}$ & $\begin{array}{c}\text { Azhikode } \\
\text { Panchayat }\end{array}$ \\
\hline $\begin{array}{c}\text { Total Population } \\
\text { Avg. percapita } \\
\text { consumption, L }\end{array}$ & $\begin{array}{c}436527 \\
\text { Total water use, }\end{array}$ & 63155 & 51770 & 23525 & 25522 & 45950 \\
$\quad$ MLD & 67.22 & 148 & 183 & 165 & 154 & 158 \\
$\begin{array}{c}\text { Waste water, } \\
\text { MLD }\end{array}$ & 53.78 & 7.5 & 9.5 & 3.9 & 3.93 & 7.2 \\
Greywater, MLD & 32.27 & 4.5 & 7.6 & 3.1 & 3.14 & 5.8 \\
\hline
\end{tabular}

\subsection{Wastewater Disposal}

Wastewater disposal is a major challenge in the State. From the survey, it was found that majority (as much as $61 \%$ ) of the families are discharging their liquid and solid wastes directly into either the drainage channels/irrigation channels or to the open spaces (Figure 4). A little more than one third of them are disposing them to pits. However, irrespective of the income status, $1 / 5^{\text {th }}$ of the surveyed people do not mind to throw their wastes to open spaces.

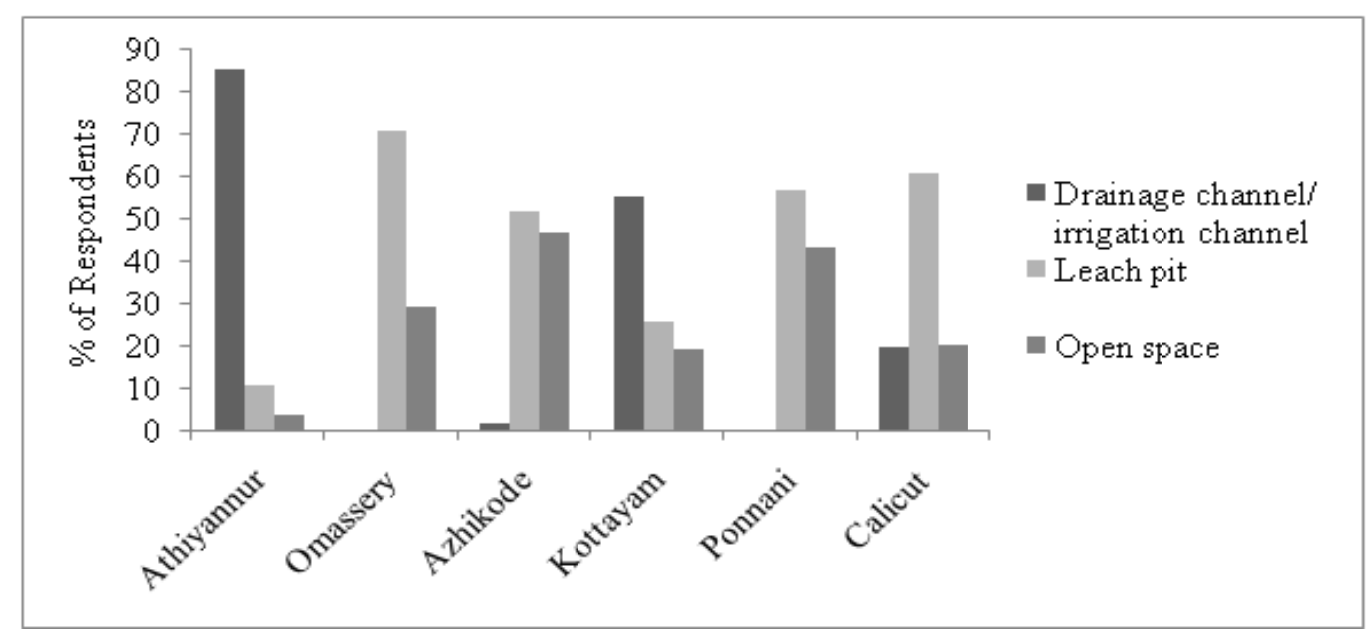

Figure 4. Mode of wastewater disposal in the study areas

Natural water bodies are receptacle to the discharge of wastewater. In Athiyannur panchayat, $86 \%$ of the surveyed people disposed their wastes directly to the irrigation channel of the Neyyar Irrigation Project. The wastewater from Omassery Panchayat discharges into a stream present near to the Panchayat. The wastewater generated from the textile units of Azhikode Panchayat is directly discharge to the Valapatanam River with out any treatment. The wastewater generated in Kottayam town is directly discharging into the Meenachil River with out any treatment through various canals and streams. The wastewater generated in Ponnani Municipality is flowing through an artificially constructed canal finally flowing to Arabian Sea. The water bodies in and around Calicut city are turning into permanent sinks and receptacles to urban wastewater. Wastewater is indiscriminately discharged, without treatment, into the sea, Cannoly canal and wetlands/waterlogged areas. There are around 10 wastewater outlets to the sea and almost the same number to the Cannoly canal. The available information 
indicates that, the wastewater management of the State is inadequate and it is presently turning into a major threat to natural water bodies of the State.

\subsection{Wastewater Characteristics}

A total number of 59 wastewater samples were collected from various wastewater discharging points of the study area. Two sets of samples were collected during monsoon (July, 2009) and post monsoon seasons (October, 2009) and analysed for various physico-chemical and biological parameters. The maximum and minimum concentration of various water quality characteristics are shown in Table 6.

Table 6. Comparison of wastewater characteristics in various study area

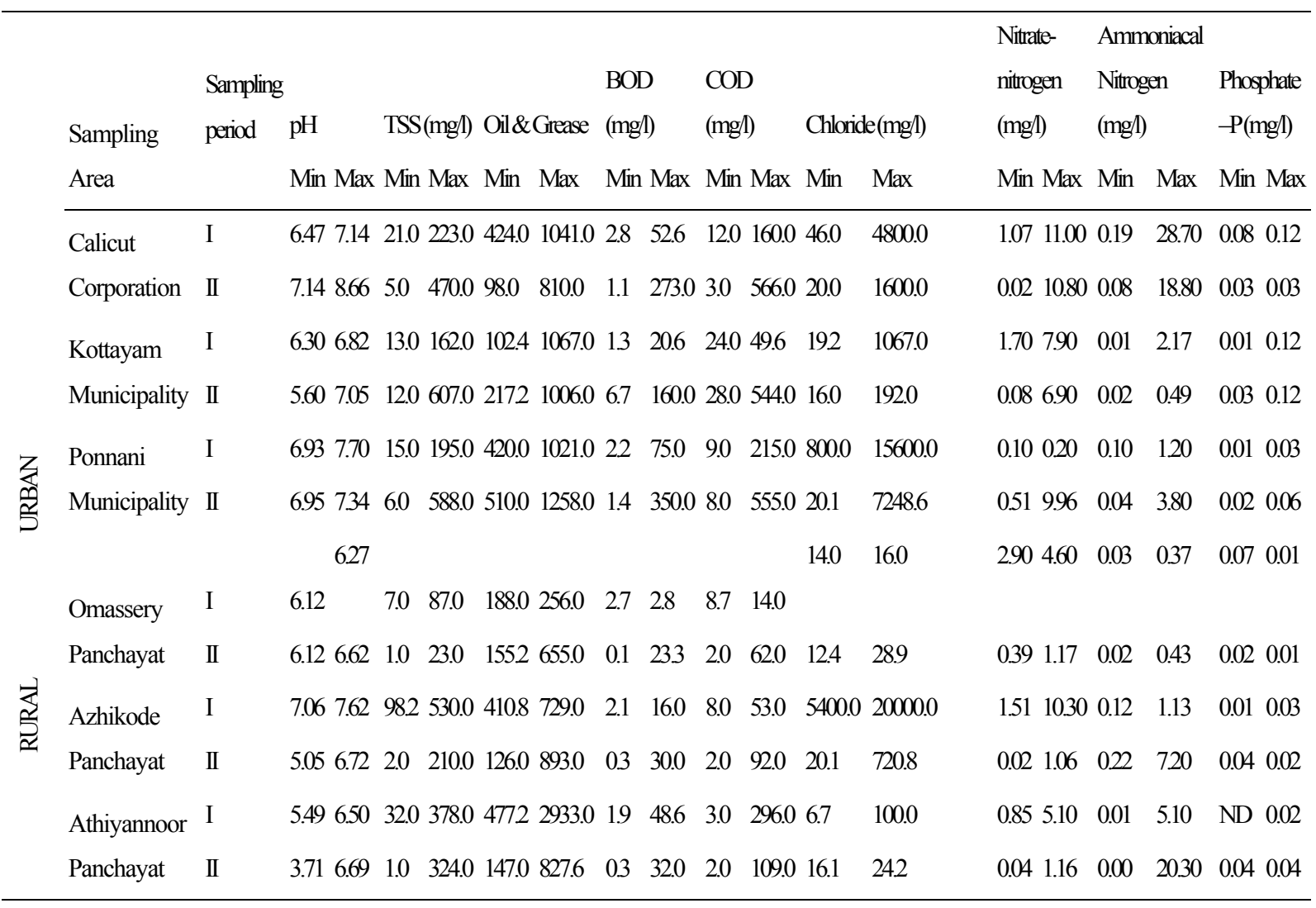

Wastewater samples collected from various study areas were mainly polluted with organic compounds. The maximum concentration of TSS, COD and BOD were found in the samples collected form the urban area especially during the post monsoon season.TSS concentration were also high in some of the samples collected from Azhikode Panchayat and Athiyannoor Panchayat. The concentration of oil and grease were found to be high in almost all sampling stations. All the wastewater samples collected from various study area were highly contaminated with coliform bacteria Fecel colifom and $E$ coli.

\subsection{Workshops/Discussions}

We had conducted several workshops/discussions to sensitise the people and various stakeholders on the existing status, possibilities and available technologies for proper wastewater management. Some of the suggestion put forwarded as part workshop are given below.

- Establish a separate Authority or Agency for wastewater management

- The topic of waste management may be introduced in the academic curriculum

- Implement decentralized treatment system at various locations

- Storm water drains may be separated from sewage water.

- Appropriate building rule shall be introduced to treat and reuse the wastewater in flats and housing colonies

- Reduce the per capita consumption of water through awareness programmes 
- Wastewater treatment may be carried out in domestic, community and Panchayat/ Municipality/ Corporation level

- Groundwater recharging may be popularized

\subsection{Wastewater Treatment-Constructed Wetland}

We are suggesting an effective wastewater treatment technology for the recycling of wastewater. Centre for Water Resources Development and Management (CWRDM), Calicut conducted a pilot study for wastewater recycling through constructed wetland technology. The wastewater was allowed to pass through six different tanks viz, sedimentation tank, skimming tank, filtration tank, storage tank, constructed wetland, and finally the treated water is collected in another storage tank. The plants Scripus Lacustris, Phragmites, Acorus calamus and Lagenandra meeboldi were used for the treatment of wastewater. The water samples collected from different tanks were subjected to various physic- chemical and bacteriological analysis (see Table 7).

Table 7. Concentration of different constituents in the inflow and outflow water of constructed wetland

\begin{tabular}{llll}
\hline Parameter & Inflow & Outflow & $\%$ Removal \\
\hline BOD $(\mathrm{mg} / \mathrm{L})$ & 206 & 33 & $84 \%$ \\
COD $(\mathrm{mg} / \mathrm{L})$ & 930 & 259 & $72 \%$ \\
TSS $(\mathrm{mg} / \mathrm{L})$ & 32 & 19 & $40 \%$ \\
TKN $(\mathrm{mg} / \mathrm{L})$ & 10.08 & 1.02 & $90 \%$ \\
TotalColiform, & $\geq 2400$ & 210 & $91 \%$ \\
MPN/100 & & & \\
\hline
\end{tabular}

The analysis results indicate that biological oxygen demand (BOD), was reduced upto $84 \%$. Wetland removes BOD from surface water through decomposition of organic matter or oxidation of inorganic. The Total Kjeldahl Nitrogen (TKN) values decreases in the overall system. There is a $90 \%$ reduction of TKN noticed in the final out flowing water. Reduction in suspended solids was achieved by physical filtration. The performance of the wetland system was found to be influenced by residence time, plant canopy cover and contact between the water and the aerated root zone. The total coliform was reduced to $210 \mathrm{MPN} / 100 \mathrm{ml}$ in the out flow from a value of $\geq 2400 \mathrm{MPN} / 100 \mathrm{ml}$ in the inflowing water from canteen. Constructed wetland systems gained popularity as an effective and low-cost alternative for wastewater treatment, especially for villages and small communities (Masi et al. 2010). The results of the study indicate that the constructed wetland is eco and user friendly model for the recycling of wastewater.

\subsection{Other Treatment Options}

Direct contact of households with untreated grey water may result in health risks. Moreover, negative effects on soils and crops may develop on the long term depending on grey water characteristics. For these reasons, grey water has to be treated before reuse. Treatment systems should be chosen taking into account simplicity in operation and the cost of construction and maintenance (Halalsheh et al., 2008) Grey water management is a major challenge in both rural and urban areas in the State. For effective management of water, focus should be on management at household level. In case it cannot be managed at household level, management at the community level should be done. As far as possible, water generated at household level should be managed such that zero or minimum community waste is generated

Due to considerations related to social acceptance of the local community, it was decided that grey water produced by each household should be treated separately. Household Level Management will always be better to manage and treat domestic grey water generated in the house in the area/courtyard/land surrounding the house. Grey water treatment process at the household level mainly involves screening (grease and silt removal), soap froth removal, equalization and filtration. Some of the treatment technologies suitable for the household level grey water management are:

- Kitchen Garden with piped root zone system

- Kitchen Garden without piped root zone system

- Leach pit 


\section{- Soakage pit}

A technical note of UNICEF about solid and liquid waste management in rural area reported that, an Environmental Sanitation Institute (ESI), Sughad in Gandhinagar in Gujarat has established an effective demonstration of the management of waste water from toilets through "Root Zone Treatment Method. Nirmal Gram Nirman Kendra has put forth a concept named as "Zero Waste House" have been developed to reuse/recycle greywater generated in a household through the piped Root Zone Treatment technique (UNICEF, 2007).

Greywater generated from the public places can be managed by adopting on site management technologies. Some of the on site wastewater management technologies are,

- Plantation with intercepting chamber

- Community leach pit

- Soak away channel

- Simple process of reuse of grey water

- System of waste water treatment such as root zone system

Decentralized treatment plants at various places are suitable for proper liquid waste management in the community level, it includes constructed wetland, rotating biological reactor, trickling filters, anaerobic fixed film reactor \& extended aeration, anaerobic lagoon, aerobic pond etc. Some other advanced technological options available for the better management of liquid waste at the community level are membrane bioreactors, carbon adsorption, ion exchange, ultrafiltration and reverse osmosis etc.

\section{Discussions}

A study was carried out to prepare a sectoral plan for liquid waste management plan for Kerala State. For the study 6 local bodies were selected, which represents various physical and geographical nature of the State. The study area included local bodies with both rural and urban nature. The study aimed to determine the percapita water usage, total waste water and greywater generation, mode of wastewater disposal and technological options for wastewater treatment.

Percapita consumption of water in the study area varied from 183 litres to 148 litres which is higher than National average of $135 \mathrm{lpcd}$. The water use in the urban and rural area did not show large variation. Quality of life was found to be a determining factor in the total consumption of water in the study area. Greywater generation was high in urban area. Greywater discharge in Calicut Corporation, Kottayam Municipality and Ponnani Municipality are 32.27MLD, 4.5MLD and 4.6 MLD respectively. The quantity of greywater is comparatively less in rural areas, in which Azhikode is an exception where high amount of wastewater is generated because of the presence of large number of small scale industries. Kerala State has low coverage of sewage facilities, because of the insufficient sewage treatment facility wastewater from various place were directly discharged into natural water bodies of the State.

Treating wastewater before it is discharged to the natural water bodies reduces the risks posed to human and environmental health. Household greywater is the major component of municipal wastewater, greywater is much easier to treat and recycle. Greywater reuse reduces sewage flows and reduces the public demand on potable water supplies (WHO, 2006). Grey water is much easier to treat and safer to recycle for water usages such as toilet flushing, urban landscaping or road washing, gardening etc. An experimental study conducted using constructed wetland was proved to be an effective method for wastewater reuse; it is observed that BOD, COD, TSS, TKN and coliforms are reduced considerably.

Appropriate information and communication for sensitization among public is absolutely necessary for the successful implementation of liquid waste management. Several workshops/discussions were conducted in various places, suggestions arised from the workshop and discussions were used to prepare a sectoral plan for the liquid waste management. An effective liquid waste management plan for the local bodies can be implemented based on the following procedure:

a. Baseline and Planning

Local bodies shall conduct a survey (based on secondary and primary data sources) and establish a comprehensive baseline data with respect to liquid waste generation, collection and disposal area.

b. Implementation

The local body shall implement the liquid waste management plan in a strategic manner, prioritizing areas that 
need urgent attention and implementing long term plans in parallel. Emphasis should also be laid on sensitizing stakeholders for raising the importance of behaviour change, practices and installation for safe disposal of liquid waste.

\section{c. Selection of Appropriate Technology}

The wastewater can be managed effectively starting from domestic sector to community and advanced level. In the household level wastewater can be treated by using kitchen garden with piped root zone system, kitchen garden without piped root zone system, leach pit and soakage pit. The greywater generated at public places can be preferably managed on site by adopting the technological options such as plantation with intercepting chamber, community leach pit, soak away channel, root zone treatment etc. For the recycling of greywater in community level, different treatment options are available are, rotating biological reactor, oxidation pond, conventional tricking filter with sludge digester, anaerobic fixed film reactor \& extended aeration, anaerobic lagoon, aerobic pond, membrane bioreactors, carbon adsorption, ion exchange, ultrafiltration and reverse osmosis etc etc.

\section{References}

Ahmad, J., Abbas, A. O., Lama, A. Q., \& Niveen, A. G. (2006). Assesment of Availability and Cahrecteristics of Greywater in Amman. International Water Resource Association, 31(2), 210-220.

American Public Health Association (APHA). (2006). Standard Method for the Examination of Water and Wastewater ( $21^{\text {st }}$ ed.). Centennial Edition, Washington DC.

Environmental Monitoring Programme on Water Quality. (2009). Environmental Monitoring Programme on Water Quality. Centre for Water Resource Development and Management (CWRDM) - Kerala State Council for Science Technology and Environment, Kerala India.

Halalsheha, M., Dalahmehb, S., Sayedb, M., Suleimanb, W., Shareefc, M., Mansourd, M., \& Safie, M. (2008). Grey water characteristics and treatment options for rural areas in Jordan. Bioresource Technology, 99, 6635-6641. http://dx.doi.org/10.1016/j.biortech.2007.12.029

Hydrology Project- Kerala. (2011). Hydrology Project- Kerala, Water Resources Development, Government of Kerala. http://hpkerala.org

Innocent Nhapi, Hubb Gijzen, J. (2005). A Strategic Framework for Managing Watewater- A Case Study of Harare, Zimbawe. Internatonal Water Resource Association, 30(4), 456-467

Masi, F., El, H. B., Abdel S. H., Baban, A., Ghrabi, A., \& Regelsberger, M. (2010). Treatment of segregated black/grey domestic wastewater using constructed wetlands in the Mediterranean basin. Water Science and Technology, 61(1), 97-105. http://dx.doi.org/10.2166/wst.2010.780

Pawan, L., Dyanand, P., Sathish, W., \& Tapan, C. (2009). India Facing Fiture Resource Constraints. International Water Association - Year Book, 38-39.

Sahar, D. S., Moayied, A., \& Wael, S. T. (2009). Themes of stakeholder participation in greywater management in rural communities in Jordan. Desalination, 243, 159-169. http://dx.doi.org/10.1016/j.desal.2008.04.022

Srinivas, P., Raveendra, K. V., \& Pradeep, K. G. N. (2008). Studies on the Possibilities of Wastewater Irrigation of the Sewage Effluent from the Designed Sewage Treatment System of Suda, A.P., India. Pollution Research, 27(2), 247-252.

UNDP. (2006) United Nations Development Programme-Human Development Programme-2006. http://hdr.undp.org/hdr2006

UNICEF. (2007). Solid and liquid waste management in rural area- a technical note. http://indiasanitationportal.org/site/default/files/slwm_20-08-07.pdf

World Health Organisation [WHO]. (2006). Overview of greywater management Health considerations. Discussed and approved at the regional consultation on national priorities and plans of action on anagement and reuse of wastewater, Amman, Jordan. Report number: WHO-EM/CEH/125/E. 